\title{
OPTIMASI CAMPURAN AVICEL PH 101 DAN LAKTOSA SEBAGAI BAHAN PENGISI PADA TABLET EKSTRAK BUNGA ROSELLA (Hibiscus sabdariffa L.) DENGAN METODE GRANULASI BASAH
}

\author{
Zila Tjhia Kokafrinsia ${ }^{1}$,Dwi Saryanti ${ }^{2}$ \\ ${ }^{1,2}$ Departemen Obat Tradisional Prodi DIII Farmasi STIKES Nasional \\ Email korespondensi : zilatjhia27@gmail.com
}

\begin{abstract}
ABSTRAK
Bunga Rosella (Hibiscuss sabdariffa L.) dalam pengobatan tradisional dapat berkhasiat untuk memberikan perlindungan terhadap berbagai penyakit, seperti jantung koroner, kanker, menurunkan kolesterol, gangguan hati. Penelitian ini bertujuan untuk mendapatkan formula optimum tablet ekstrak bunga rosella dari campuran Avicel PH 101 dan Laktosa sebagai bahan pengisi dengan metode granulasi basah. Ekstrak bunga rosella diperoleh dengan maserasi serbuk bunga rosella menggunakan etanol $70 \%$. Optimasi formula tablet dengan metode Simplex Lattice Design menggunakan software Design Expert versi 10. Parameter yang digunakan dalam optimasi adalah waktu keragaman bobot, kekerasan, kerapuhan dan waktu hancur tablet. Verifikasi formula optimal dengan menggunakan program SPSS 18 dengan metode One Sample T-test dengan taraf kepercayaan 95\%. Hasil penelitian menunjukkan formula optimal tablet ekstrak bunga rosella dengan perbandingan formula Avicel PH 101 97,82\% : Laktosa $2,17 \%$. Formula optimal mempunyai keragaman bobot yaitu $1,53 \% \pm 0,0073$; kekerasan $5,087 \mathrm{~kg} \pm 0,5135$; kerapuhan yaitu $0,3 \% \pm 0,041$. Waktu hancur yang dihasilkan tidak memenuhi persyaratan yaitu 22,99 menit $\pm 2,218$. Hasil verifikasi formula otimal menunjukkan bahwa tidak terdapat perbedaan yang signifikan antara prediksi dari metode Simplex Lattice Design dengan hasil pengujian yang dilakukan sehingga dapat dikatakan metode tersebut valid.
\end{abstract}

Kata kunci: Formula optimal, Simplex Lattice Design, kekerasan, kerapuhan, waktu hancur 


\title{
OPTIMIZATION OF AVICEL PH 101 AND LACTOSE AS A FILLER IN TABLET OF ROSELLA (Hibiscus sabdariffa L.) FLOWER EXTRACT WITH WET GRANULATION
}

\begin{abstract}
Rosella flower (Hibiscuss sabdariffa L.) in traditional medicine can provide protection against various diseases, such as coronary heart disease, cancer, lowering cholesterol, and liver disorders. This study aims to obtain the optimum formula of tablet of rosella flower extract with a mixture of Avicel PH 101 and lactose as a filler using wet granulation method. Rosella flower extract was obtained by maceration of rosella flower powder using $70 \%$ ethanol. The optimization formula for tablets using the Simplex Lattice Design method with Design Expert software version 10. The parameters used in the optimization are weight variation, hardness, friability and disintegration time. Verification of the optimal formula using the SPSS 18 program with the One Sample T-test method with a confidence level of 95\%. The results showed that the optimal formula of tablet of rosella flower extract was the Avicel PH 101 97.82\%: $2.17 \%$ lactose. The optimal formula has weight variation $1.53 \% \pm 0.0073$; hardness $5.087 \mathrm{~kg} \pm 0.5135$; the friability is $0.3 \% \pm 0.041$. The resulting disintegration was 22.99 minutes \pm 2.218 . The results of the verification of the optimal formula show that there is no significant difference between the predictions of the Simplex Lattice Design method and the results of the tests performed so that it can be said that the method is valid.
\end{abstract}

Keywords: optimal formula, Simplex Lattice Design, hardness, friability, disintegration time.

\section{PENDAHULUAN}

Indonesia merupakan negara yang memberikan perlindungan dengan sumber daya alam yang sangat beragam. Bahan alam merupakan bahan yang berasal dari tanaman maupun hewan, baik dalam keadaan budidaya atau yang dibiarkan tanpa pemeliharaan secara khusus. Salah satu tanaman yang bisa dimanfaatkan sebagai pengobatan yaitu Bunga Rosella (Hibiscus sabdariffa L.). Bunga Rosella mengandung senyawa seperti gossipetin, antosianin, dan flavonoid terhadap berbagai penyakit degeneratif seperti jantung coroner, kanker, menurunkan kolesterol, gangguan hati, dan juga berkhasiat sebagai antioksidan (Mahadevan dkk, 2009). Menurut penelitian Adetutu dkk (2013) menyatakan bahwa rosella memilki efek hepatoprotektor dan antioksidan pada tikus wistar dengan dosis $50 \mathrm{mg} / \mathrm{kgBB}$.

Tablet adalah sediaan padat mengandung bahan obat dengan atau 
tanpa bahan pengisi (Depkes RI, 1995). Metode yang digunakan dalam pembuatan tablet adalah granulasi basah. Pemilihan metode ini dikarenakan senyawa antosianin relatif tahan terhadap pemanasan maksimal suhu $50^{\circ} \mathrm{C}$. Metode granulasi basah adalah proses menambahkan cairan pada suatu serbuk atau campuran serbuk dalam suatu wadah yang dilengkapi dengan pengadukan yang akan menghasilkan aglomerasi atau granul (Siregar dan Wikarsa, 2010).

Bahan pengisi adalah suatu bahan inert secara farmakologis yang ditambahkan kedalam suatu formulasi sediaan tablet yang bertujuan untuk penyesuaian bobot, ukuran tablet sesuai yang dipersyaratkan, untuk membantu kemudahan dalam pembuatan tablet, dan meningkatkan mutu sediaan tablet (Siregar dan Wikarsa, 2010). Avicel PH 101 memiliki harga yang relatif mahal, tetapi Avicel dapat digunakan sebagai bahan pengikat, pengisi, penghancur, dan pelicin dalam pembuatan tablet. Laktosa digunakan bersama dengan avicel PH 101 karena laktosa memiliki stabilitas yang baik dalam kombinasinya dengan bahan lain dan dari sisi ekonomi,laktosa relatif murah (Hayatus dan Fudholi, 2011). Laktosa memiliki kekurangan yaitu sifat alir yang kurang baik sehingga dalam penelitian ini digunakan metode granulasi basah untuk memperbaiki sifat alirnya.

Optimasi formula campuran Avicel PH 101 dan Laktosa dengan menggunakan metode Simplex Lattice Design dalam software Design Expert versi 10. Optimasi digunakan untuk mendapatkan formula terbaik. Metode ini digunakan untuk menentukan formula optimal Avicel PH 101 dan Laktosa sebagai bahan pengisi.

Berdasarkan latar belakang diatas, maka dilakukan penelitian tentang optimasi campuran Avicel PH 101 dan Laktosa sebagai bahan pengisi pada tablet ekstrak bunga rosella (Hibiscus sabdariffa L.) secara granulasi basah.

\section{ALAT DAN BAHAN \\ Alat}

Alat yang digunakan adalah mortir dan stamfer, blender (Cosmos), timbangan elektrik (Acis), oven (Memmert), alat ukur waktu alir, alat gelas (Pyrex), waterbath (Memmert), hardness tester (YD-1), friabilitator (Unilab), disintegration tester (BJ-1) mesin cetak tablet, stopwatch.

\section{Bahan}

Bahan yang digunakan adalah bunga rosela yang diperoleh dari desa Karanglo, Argomulyo Sedayu, Bantul, Yogyakarta, Ethanol 70\% (PT.Brataco), Avicel PH 101 (PT.Brataco), Laktosa (PT.Brataco), Gelatin (PT.Brataco), Magnesium Stearat (PT.Brataco), Talk (PT.Brataco), Aerosil.

\section{METODE PENELITIAN}

Pembuatan Ekstrak Bunga Rosella

Serbuk bunga Rosella kering dimaserasi dengan penyari etanol $70 \%$. Sebanyak 3 kilogram serbuk bunga rosella direndam dalam bejana kaca dengan etanol $70 \%$ dengan perbandingan 1:5. Serbuk direndam 
dengan ethanol sebanyak 6 liter selama 3 hari. Selama waktu tersebut, setiap 24 jam, rendaman ekstrak diaduk selama 5 menit. Hasil penyaringan dipekatkan menggunakan waterbath dengan suhu $50^{\circ} \mathrm{C}$ (Asiani, 2012).

\section{Pembuatan Tablet Ekstrak Bunga Rosella}

Tabel 1. Formula Tablet Ekstrak Bunga Rosella

\begin{tabular}{|c|c|c|c|c|c|c|c|c|}
\hline \multirow{2}{*}{ Komposisi } & \multicolumn{8}{|c|}{ Berat bahan (mg) } \\
\hline & 1 & 2 & 3 & 4 & 5 & 6 & 7 & 8 \\
\hline $\begin{array}{l}\text { Ekstrak bunga } \\
\text { Rosella }\end{array}$ & 280 & 280 & 280 & 280 & 280 & 280 & 280 & 280 \\
\hline Avicel PH 101 & 22 & 88 & 0 & 0 & 44 & 44 & 88 & 66 \\
\hline Laktosa & 66 & 0 & 88 & 88 & 44 & 44 & 0 & 22 \\
\hline Gelatin & 25 & 25 & 25 & 25 & 25 & 25 & 25 & 25 \\
\hline $\mathrm{Mg}$ stearate & 0,7 & 0,7 & 0,7 & 0,7 & 0,7 & 0,7 & 0,7 & 0,7 \\
\hline Talk & 6,3 & 6,3 & 6,3 & 6,3 & 6,3 & 6,3 & 6,3 & 6,3 \\
\hline Aerosil & 100 & 100 & 100 & 100 & 100 & 100 & 100 & 100 \\
\hline Bobot & 500 & 500 & 500 & 500 & 500 & 500 & 500 & 500 \\
\hline
\end{tabular}

Pembuatan tablet ekstrak bunga rosella ditambah dengan aerosil 100mg dan diaduk hingga kering. Kemudian menimbang ekstrak yang telah kering dan ditambahkan Avicel PH 101 dan laktosa dengan jumlah yang berbeda, kemudian campur hingga homogen. Setelah didapatkan campuran Avicel PH 101, laktosa dan ekstrak bunga rosella yang telah menjadi serbuk, kemudian ditambahkan gelatin yang telah dilarutkan dalam air sebanyak $0,5 \mathrm{~mL}$ yang berperan sebagai bahan pengikat. Kemudin massa granul diayak dengan ayakan nomor 14 membentuk granul basah. Granul basah dikeringkan di oven dengan suhu $40-45^{\circ} \mathrm{C}$. Setelah kering, granul diayak dengan ayakan nomor 16, kemudian ditambahkan Talk dan Magnesium stearat. Setelah itu dilakukan uji sifat alir granul, uji kadar air granul, dan uji sudut diam granul. Granul yang telah diuji, kemudian dikempa dengan mesin tablet dengan berat $500 \mathrm{mg}$.

\section{Optimasi Formula Tablet Esktrak Bunga Rosella}

Penentuan formula optimum menggunakan metode Simplex Lattice Design dengan software Design Expert versi 10 dengan parameter uji sifat fisik tablet meliputi uji keragaman bobot tablet, uji kekerasan, uji kerapuhan, serta uji waktu hancur. Apabila nilai desirability mendekati nilai 1,0 maka menunjukkan kemampuan program 
untuk memprediksi parameter optimasi dalam suatu sediaan (Raissi dan Farzani, 2009).

\section{Evaluasi Granul Ekstrak Bunga Rosella}

\section{Pengujian Sifat Alir Granul}

kecepatan alir $=\frac{\text { bobot }(g)}{\text { waktu }(\text { detik })}$

\section{Pengujian Sudut Diam Granul}

Sudut diam merupakan sudut yang dibentuk antara tinggi yang terbentuk oleh serbuk atau granul yang telah diberi perlakuan. Bila sudut diam lebih kecil atau sama dengan $30^{\circ}$

$\tan \mathrm{a}=\frac{h}{r}$

\section{Pengujian Kadar Air Granul}

Penentuan kadar granul dilakukan dengan menghitung kandungan Lembab (MC). Sejumlah 5
Granul seberat $100 \quad \mathrm{~g}$ dimasukkan dalam corong dan bawah corong ditutup. Penutup corong dibuka kemudian alat pencatat waktu dihidupkan sampai semua serbuk atau granul keluar dari corong.

$\frac{\text { Bobot granulbasah-bobot granulkering }}{\text { bobot granul kering }} \times 100 \%$

biasanya menunjukkan bahwa bahan yang digunakan dapat mengalir bebas, bila sudutnya lebih besar atau sama dengan $40^{\circ}$ biasanya daya mengalirnya kurang baik (Hayatus dan Fudholi, 2011). (persamaan 1)

\section{Evaluasi Tablet Ekstrak Bunga}

\section{Rosella}

\section{Uji Keragaman Bobot}

Tablet sebanyak 20 ditimbang satu persatu dan dihitung bobot rata rata tiap tablet ditentukan nilai coefisien variation $(\mathrm{CV})$ dari hasil penimbangan tersebut. Bobot dikatakan seragam jika CV $<5 \%$ (Wacana, 2016).

\section{Uji Kekerasan}

Uji kekerasan dilakukan dengan menggunakan alat hardness tester. Skala yang muncul pada alat menunjukkan kekerasan tablet yang diukur dengan satuan kilogram. Kekerasan tablet yang baik yaitu 4-8 kg (Parrot, 1971). 


\section{Uji Kerapuhan}

Bersihkan 20 tablet ekstrak Bunga Rosella dari debu yang melekat pada tablet, kemudian ditimbang, lalu dimasukkan dalam alat friabilator. Alat diatur dengan kecepatan 25 rpm selama 4 menit. Kerapuhan tablet dihitung dari pengurangan berat tablet akibat perlakuan. Kerapuhan tablet dikatakan baik jika presentase kerapuhan dibawah 1\% (Sulaiman, 2007).

\section{Uji Waktu Hancur}

Uji waktu hancur dilakukan dengan cara 6 tablet dimasukkan dalam keranjang, kemudian dinaik turunkan secara teratur sebanyak 30 kali tiap menit. Tablet dinyatakan hancur apabila tidak ada bagian tablet yang tertinggal di atas kasa, kecuali fragmen yang berasal dari zat penyalut. Kecuali diyatakan lain, waktu yang diperlukan untuk tablet hancur yaitu tidak lebih dari 15 menit untuk tablet tidak bersalut (Depkes RI, 2014).

\section{Analisis Data}

Penentuan formula optimum menggunakan metode Simplex Lattice Design dengan software Design Expert versi 10 dengan parameter uji sifat fisik tablet meliputi uji keragaman bobot tablet, uji kekerasan, uji kerapuhan, serta uji waktu hancur. Verifikasi formula optimal tablet diuji dengan bantuan progam SPSS dengan metode One Sample T-test.

\section{HASIL DAN PEMBAHASAN Hasil Ekstraksi Bunga Rosella}

Sampel yang digunakan dalam penelitian ini adalah Bunga Rosella (Hibiscus sabdariffa L.) yang diperoleh dari desa Karanglo, Argomulyo Sedayu, Bantul, Daerah Istimewa Yogyakarta. Sampel yang telah didapat, dilakukan proses determinasi terlebih dahulu di Laboratorium Biologi Universitas Muhammadiyah Surakarta, didapatkan hasil bahwa sampel yang digunakan benar merupakan Bunga Rosella (Hibiscus sabdariffa L.). Rosella dikeringkan memiliki tujuan untuk menurunkan kadar air yang terkandung dalam bunga rosella itu sendiri. Metode pengeringan yang digunakan untuk mengeringkan bunga rosella yaitu dengan sinar matahari selama 3-5 hari (Rita dkk, 2011). Tujuan penghalusan yaitu untuk memperluas permukaan partikel simplisia sehingga semakin besar kontak permukaan partikel simplisia dengan pelarut dan mempermudah penetrasi pelarut kedalam simplisia sehingga dapat menarik senyawa-senyawa dari simplisia lebih banyak (Elidahanum, 2018).

Pembuatan ekstrak bunga rosella dilakukan dengan metode dingin yaitu metode maserasi. Hal ini disebabkan karena senyawa antosianin yang terkandung dalam bunga rosella tidak tahan terhadap pemanasan melebihi $50^{\circ} \mathrm{C}$ dan metode maserasi merupakan metode yang mudah dan sederhana. Pelarut yang digunakan dalam maserasi ini yaitu etanol $70 \%$ dikarenakan etanol $70 \%$ memiliki sifat kepolaran yang mendekati sifat kepolaran senyawa yang ada dalam bunga rosella yaitu senyawa 
antosianin yang berfungsi sebagai antioksidan. Pemekatan sari ekstrak dilakukan dengan menggunakan alat rotary evaporator dengan suhu $45^{\circ} \mathrm{C}$ dan dengan kecepatan 200rpm untuk mendapatkan ekstrak yang kental, pemekatan dipindahkan diatas waterbath. Parameter bahwa ekstrak dikatakan sudah mengental apabila ekstrak tidak dapat dituang.

Hasil perhitungan rendemen ekstrak bunga rosella terhadap bunga rosella adalah 3 kilogram serbuk kering dihasilkan ekstrak kental bunga rosella 319 gram. Dari data tersebut diperoleh rendemen bunga rosella sebesar 10,63
\%. Pada penelitian Nirmalasari pada tahun 2014 rendemen ekstrak bunga rosella yang dihasiklkan sebesar $13,59 \%$.

\section{Hasil Evaluasi Sifat Fisik Granul Esktrak Bunga Rosella}

Pemeriksaan granul dilakukan agar didapatkan tablet berkualitas baik. Sifat alir granul sangat penting dalam pembuatan tablet karena apabila sifat alir granul baik, maka saat proses pencetakan tablet menghasilkan keragaman tablet yang baik. Hasil pengujian sifat fisik granul dapat dilihat pada table 2 .

Tabel 2. Hasil Uji Sifat Fisik Granul Ekstrak Bunga Rosella

\begin{tabular}{ccccccccc}
\hline Uji Kualitas Fisik & Run & Run & Run & Run & Run & Run & Run & Run \\
& $\mathbf{1}$ & $\mathbf{2}$ & $\mathbf{3}$ & $\mathbf{4}$ & $\mathbf{5}$ & $\mathbf{6}$ & $\mathbf{7}$ & $\mathbf{8}$ \\
\hline $\begin{array}{c}\text { Kecapatan alir } \\
\text { (g/detik) }\end{array}$ & 94,33 & 41,49 & 60,60 & 60,14 & 50,00 & 47,84 & 42,19 & 51,54 \\
$\quad \begin{array}{c}\text { Kadar air (\%) } \\
\text { (\%) }\end{array}$ & 2,10 & 2,40 & 3,32 & 3,49 & 2,23 & 2,17 & 4,46 & 3,66 \\
\hline
\end{tabular}

Berdasarkan hasil pengujian kecepatan alir pada table 2 dapat dilihat bahwa semua formula mempunyai kecepatan alir yang baik dan memenuhi persyaratan yaitu > 10 gram/detik. Hasil uji kadar air granul menunjukkan bahwa semua formula yang dihasilkan memenuhi persyaratan kadar air yaitu 15\% (Elisabeth, 2018). Kadar air yang terlalu rendah dapat menyebabkan granul yang dihasilkan mempunyai kerapuhan yang tinggi, sedangkan jika terlalu tinggi kadar air maka akan menghasilkan granul yang sukar mengalir.

\section{Hasil Uji Kualitas Fisik Tablet Esktrak Bunga Rosella}

Hasil uji kualitas fisik tablet ekstrak bunga rosella yang dihasilkan dapat dilihat pada table 3 . 
Tabel 3. Hasil Uji Kualitas Fisik Tablet Ekstrak Bunga Rosella

\begin{tabular}{ccccccccc}
\hline Uji Kualitas Fisik & Run & Run & Run & Run & Run & Run & Run & Run \\
& $\mathbf{1}$ & $\mathbf{2}$ & $\mathbf{3}$ & $\mathbf{4}$ & $\mathbf{5}$ & $\mathbf{6}$ & $\mathbf{7}$ & $\mathbf{8}$ \\
\hline $\begin{array}{c}\text { Keragaman Bobot } \\
(\% \mathbf{C V})\end{array}$ & 5,69 & 1,58 & 4,66 & 4,55 & 3,61 & 3,66 & 1,47 & 1,98 \\
$\begin{array}{c}\text { Kekerasan } \\
\text { (Kilogram) }\end{array}$ & 3,501 & 5,474 & 2,262 & 2,358 & 5,287 & 5,399 & 5,527 & 1,857 \\
$\begin{array}{c}\text { Kerapuhan(\%) } \\
\begin{array}{c}\text { Waktu Hancur } \\
\text { (menit) }\end{array}\end{array}$ & 0,418 & 0,253 & 0,829 & 0,836 & 0,499 & 0,465 & 0,254 & 0,767 \\
\hline
\end{tabular}

Optimasi Formula Tablet Ekstrak

\section{Bunga Rosella}

\section{Hasil Uji Keragaman Bobot}

Keragaman bobot dapat menggambarkan keseragaman kadar zat aktif dengan anggapan bahwa campuran masa yang dikempa homogen maka dipastikan kadar bahan zat aktif akan seragam jika bobot tablet hasil pengempaan seragam pula. Kecepatan alir granul mempengaruhi keseragaman bobot tablet. Semakin lambat kecepatan alir, maka keseragaman bobot makin tidak seragam. Contour plot yang dihasilkan pada uji keseragaman bobot dapat dilihat pada gambar 1 .

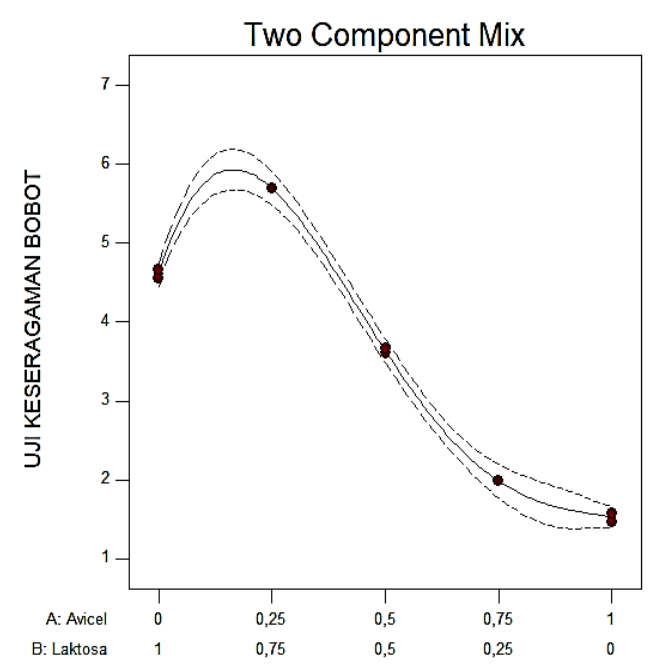

Gambar 1. Contour plot uji keragaman bobot tablet 
Contour Plot digunakan untuk mengetahui bagaimana pengaruh pada penambahan Avicel PH 101 dan Laktosa dalam tablet terhadap keragaman bobot tablet yang dihasilkan dari 8 formula. Contour plot berbentuk kubik,hal ini disebabkan karena avicel PH 101 dan Laktosa memiliki pengaruh dominan yang sama besar dalam meningkatkan bobot tablet (Sylfania, 2013).

Hasil uji terhadap keragaman bobot berdasarkan pendekatan simplex lattice design didapatkan persamaan sebagai berikut :

$$
\mathrm{Y}=1,53(\mathrm{~A})+4,60(\mathrm{~B})+2,28(\mathrm{AB})-11,57 \mathrm{AB}(\mathrm{A}-\mathrm{B})+7,31 \mathrm{AB}(\mathrm{A}-\mathrm{B})^{2}
$$

Keterangan :

$\mathrm{Y} \quad=$ keseragaman bobot

$\mathrm{A} \quad=$ proporsi Avicel $\mathrm{PH} 101$

$\mathrm{B}=$ proporsi laktosa

$(\mathrm{A})(\mathrm{B})=$ proporsi avicel $\mathrm{PH}$ 101: Laktosa

Persamaan (1) menunjukkan bahwa Laktosa memberikan pengaruh yang lebih besar dalam meningkatkan keragaman bobot tablet dibanding dengan Avicel PH 101 dan interaksi antara avicel PH 101 dan laktosa.

\section{Hasil Uji kekerasan}

Uji kekerasan merupakan parameter yang menggambarkan

ketahanan tablet dalam melawan
goncangan serta terjadinya keretakan
tablet selama pembungkusan,
pengangkutan dan pendistribusian
kepada konsumen. Secara teori,
semakin besar konsentrasi bahan
pengikat, maka semakin keras tablet
yang dihasilkan.

ketahanan tablet dalam melawan tablet selama pembungkusan, pengangkutan dan pendistribusian kepada konsumen. Secara teori, semakin besar konsentrasi bahan yang dihasilkan.

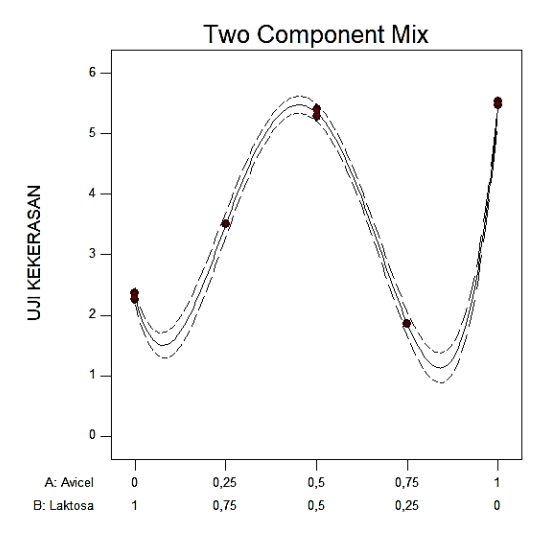

Gambar 2. Contour plot uji kekerasan tablet 
Contour plot diatas berbentuk quartic, yang berarti baik komponen avicel PH 101 maupun Laktosa yang jumlah konsentrasi yang lebih dominan mempunyai pengaruh yang sama besar dalam tingkat kekerasan selain itu terdapat juga interaksi positif antara dua komponen yang dapat meningkatkan kekerasan pada tablet.

Hasil uji terhadap kekerasan tablet berdasarkan pendekatan simplex latice design didapatkan persamaan sebagai berikut :

$$
\mathrm{Y}=5,50(\mathrm{~A})+2,31(\mathrm{~B})+5,75(\mathrm{AB})-17,28 \mathrm{AB}(\mathrm{A}-\mathrm{B})-49,16 \mathrm{AB}(\mathrm{A}-\mathrm{B})^{2} \ldots(2)
$$

Keterangan :

$\mathrm{Y}=$ kekerasan

A $=$ proporsi Avicel PH 101

$\mathrm{B} \quad=$ proporsi laktosa

$(\mathrm{A})(\mathrm{B})=$ konsentrasi avicel PH 101: Laktosa

Dari persamaan (2) tablet terhadap pengikisan dan menunjukkan bahwa Avicel memiliki goncangan. Kerapuhan merupakan nilai yang lebih tinggi yaitu 5,50 dibandingkan dengan laktosa yaitu 2,31 yang menunjukkan bahwa avicel dapat meningkatkan kekerasan tablet.

\section{Hasil Uji Kerapuhan} kemampuan suatu tablet untuk hancur menjadi partikel yang berukuran lebih kecil pada saat terjadi goncangan atau benturan saat proses pengemasan, pendistribusian.

Uji kerapuhan dilakukan untuk mengetahui bagaimana daya tahan

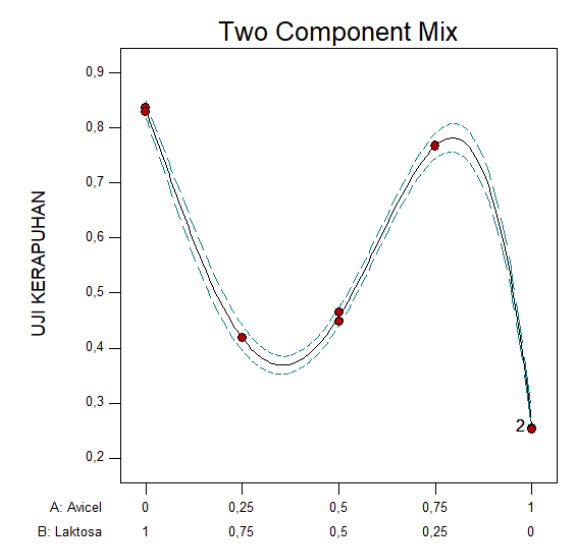

Gambar 3. Contour plot uji kerapuhan tablet 
Contour plot digunakan untuk mengetahui apakah terdapat pengaruh pada penambahan Avicel PH 101 dan Laktosa terhadap kerapuhan tablet. Contour plot diatas berbentuk quartic. Proporsi laktosa yang lebih besar memberikan pengaruh terhadap kerapuhan tablet. Hal ini dikarenakan laktosa berupa serbuk halus yang akan menghasilkan tablet yang kurang kompak sehingga lebih mudah rapuh (Sylfania, 2013).

Hasil uji terhadap kerapuhan tablet berdasarkan pendekatan simplex lattice design didapatkan persamaan sebagai berikut :

$\mathrm{Y}=0,25(\mathrm{~A})+0,83(\mathrm{~B})-0,34(\mathrm{AB})+3,41 \mathrm{AB}(\mathrm{A}-\mathrm{B})+2,43 \mathrm{AB}(\mathrm{A}-\mathrm{B})^{2} \ldots(3)$

Keterangan :

$\mathrm{Y} \quad=$ kerapuhan

$\mathrm{A} \quad=$ proporsi Avicel PH 101

$\mathrm{B} \quad=$ proporsi laktosa

$(\mathrm{A})(\mathrm{B})=$ proporsi avicel PH $101:$ Laktosa

\section{Hasil persamaan (3) Hasil Uji Waktu Hancur}

menunjukkan bahwa laktosa memiliki pengaruh yang lebih besar daripada avicel PH 101 dalam meningkatkan kerapuhan tablet. Interaksi antara Avicel PH 101 dan Laktosa menghasilkan interaksi yang negatif yang artinya kombinasi keduanya dapat menurunkan kerapuhan tablet.

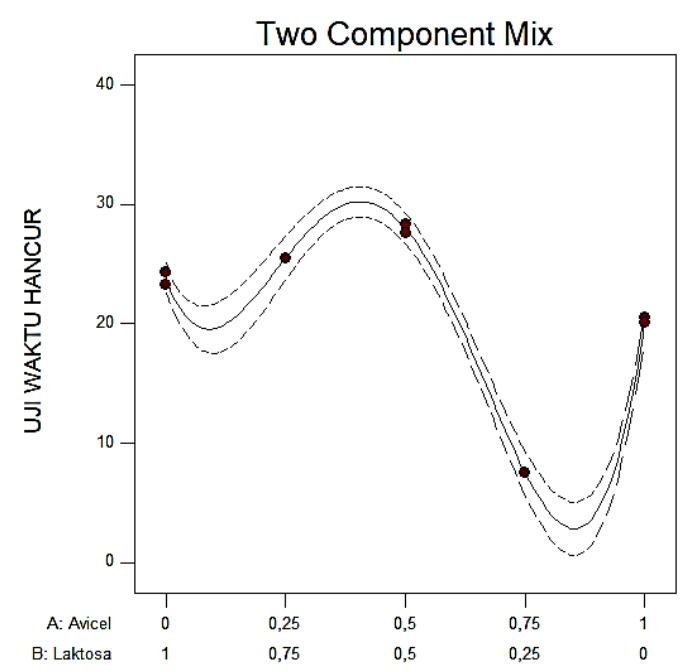

Uji waktu hancur tablet dilakukan untuk mengetahui perkiraan waktu yang dibutuhkan tablet untuk hancur setelah berada didalam tubuh.

Gambar 4. Contour plot Hasil Uji Waktu Hancur Tablet 
Contour plot diatas berbentuk quartic, yang berarti terdapat interaksi yang terjadi pada campuran avicel $\mathrm{PH}$ 101 dan laktosa sehingga akan meningkatkan waktu hancur tablet.
Hasil uji terhadap kerapuhan tablet berdasarkan pendekatan simplex lattice design didapatkan persamaan sebagai berikut :

$\mathrm{Y}=20,32(\mathrm{~A})+23,82(\mathrm{~B})+23,62(\mathrm{AB})-86,61 \mathrm{AB}(\mathrm{A}-\mathrm{B})-212,77 \mathrm{AB}(\mathrm{A}-\mathrm{B})^{2} \ldots(4)$

Keterangan :

$\mathrm{Y} \quad=$ Waktu hancur

A $\quad=$ proporsi Avicel PH 101

$\mathrm{B}=$ proporsi laktosa

$(\mathrm{A})(\mathrm{B})=$ proporsi avicel PH $101:$ Laktosa

Avicel PH 101 bekerja dengan cara wicking action (perembesan) yaitu bagian tablet kontak dengan cairan maka air akan segera masuk kedalam tablet melalui saluran pori-pori yang terbentuk selama proses pembuatan tablet. Sifat hidrofibilitas dari avicel mengakibatkan perembesan air lewat pori lebih cepat dan efektif sehingga dapat menghancurkan tablet lebih cepat (Voigt, 1995). Persyaratan waktu hancur untuk tablet tidak bersalut yaitu < 15 menit (Depkes RI, 1995).

\section{Penentuan Formula Optimal Berdasarkan Simplex Lttice Design}

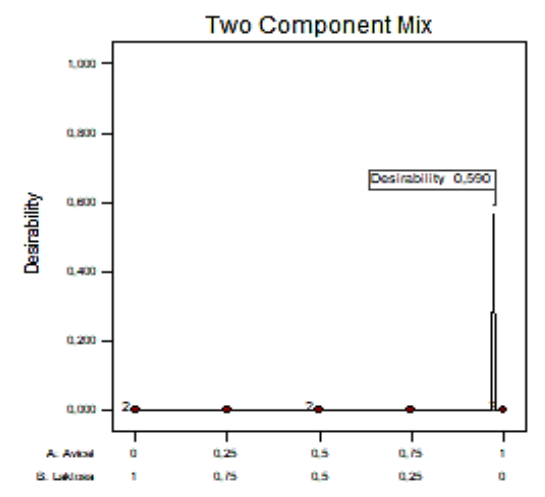

Gambar 5. Contour plot formula optimal dengan pendekatan Simplex Lattice Design

Dilihat dari gambar 5, tablet bunga rosella yang diperoleh dari metode simplex lattice design dengan proporsi avicel PH 101 yaitu 97,82\% dan laktosa $2,17 \%$ yang memiliki respon paling optimal, dengan nilai desirability 0,590. Nilai desirability yang diperoleh pada formula optimum yaitu 0,590. Jika nilai desirability yang dihasilkan semakin mendekati 1,0 maka semakin tinggi nilai ketepatan optimasi. 
Tabel 3. Hasil Verifikasi Formula Optimal Tablet Ekstrak Bunga Rosella

\begin{tabular}{ccccc}
\hline Parameter & Prediksi & $\begin{array}{c}\text { Hasil } \\
\text { pengujian }\end{array}$ & Signifikasi & Interpretasi \\
\hline $\begin{array}{c}\text { Keragaman } \\
\text { bobot }(\% \mathbf{C V})\end{array}$ & 3,635 & $1,59 \pm 0,196$ & 0,979 & $\begin{array}{c}\text { Tidak berbeda } \\
\text { signifikan }\end{array}$ \\
$\begin{array}{c}\text { Kekerasan } \\
\text { (kilogram) }\end{array}$ & 5,343 & $5,08 \pm 0,513$ & 1,000 & $\begin{array}{c}\text { Tidak berbeda } \\
\text { signiikan }\end{array}$ \\
$\begin{array}{c}\text { Kerapuhan } \\
(\%)\end{array}$ & 0,457 & $0,35 \pm 0,041$ & 0,990 & $\begin{array}{c}\text { Tidak berbeda } \\
\text { signifikan }\end{array}$ \\
$\begin{array}{c}\text { Waktu hancur } \\
\text { (menit) }\end{array}$ & 27,975 & $22,98 \pm 2,202$ & 1,000 & $\begin{array}{c}\text { Tidak berbeda } \\
\text { signifikan }\end{array}$ \\
\hline
\end{tabular}

Verifikasi Formula Optimal Tablet Ekstrak Bunga Rosella

Berdasarkan tabel 3 dapat disimpulkan bahwa pada pengujian keseragaman bobot, kekerasan, kerapuhan dan waktu hancur pada sediaan tablet ekstrak bunga rosella memberikan hasil yang tidak berbeda signifikan antara pengujian dengan prediksi pada program Design Expert 10 yang digunakan sesuai. Hasil prediksi dengan hasil uji tablet meliputi uji keragaman bobot, kekerasan, kerapuhan serta uji waktu hancur tidak ada perbedaan yang signifikan. Hasil pengujian yang diperoleh sesuai dengan hasil prediksi, yang berarti metode yang digunakan untuk verifikasi formula optimum dinyatakan valid.

Berdasarkan hasil uji organoleptis yang dilakukan diperoleh hasil uji organoleptik tablet yaitu bentuk tablet bulat pipih, warna coklat tua, rasa asam dan mempunyai bau khas bunga rosella. Pengujian keseragaman bobot tablet diperoleh hasil bahwa nilai $\mathrm{CV}$ kurang dari 5\% yang menunjukkan bahwa tablet yang dihasilkan mempunyai keragaman bobot yang baik. Hasil uji keragaman bobot menunjukkan tidak terdapat perbedaan yang signifikan antara prediksi dengan hasil pengujian.

Pengujian kerapuhan tablet dilakukan untuk mengetahui persen bobot yang hilang setelah dilakukan pengujian menggunakan alat friabilitator tester. Dalam penyimpanan, persen kerapuhan mengalami penurunan. Semakin besar nilai persen kerapuhan yang dihasilkan, maka semakin besar masa tablet yang hilang, sehingga kadar zat aktif dalam tablet berkurang (Nova, 2013). Hasil uji kerapuhan menunjukkan bahwa formula tablet ekstrak bunga rosella mempunyai kerapuhan $0,345 \%$ yang artinya 
memenuhi syarat kerapuhan tablet. Syarat kerapuhan tablet adalah kurang dari $0,8 \%$.

Berdasarkan hasil uji kekerasan yang diperoleh menunjukkan bahwa kekerasan tablet ekstrak bunga rosella memenuhi syarat uji kekerasan yaitu $5,08 \mathrm{~kg}$. Syarat uji kekerasan tablet adalah 4-8 kg. Pengujian dilakukan dengan menggunakan alat disintregation tester pada suhu $37^{\circ} \mathrm{C}$ sesuai dengan suhu tubuh manusia yang sebenarnya. Faktor-faktor yang mempengaruhi waktu hancur yaitu sifat fisik granul dan kekerasan tablet (Siregar dan Wikarsa, 2010). Hasil uji waktu hancur tablet ekstrak bunga rosella sebesar 22,98 menit. Hasil ini tidak memenuhi persyaratan sediaan tablet karena waktu hancur lebih dari 15 menit. Waktu hancur yang lama disebabkan karena dalam formula digunakan gelatin sebagai bahan pengikat dan juga digunakan avicel dalam sediaan tablet tersebut. Avicel selain berfungsi sebagai bahan pengisi juga berfungsi sebagai bahan pengikat sehingga tablet yang dihasilkan memiliki waktu hancur yang tidak memenuhi persyaratan. Bahan penghancur yang digunakan tidak mampu melawan daya ikat dari kedua bahan tersebut sehingga waktu hancur menjadi lama.

\section{KESIMPULAN}

Perbandingan antara Avicel PH 101 dan Laktosa sebagai bahan penghancur dalam sediaan tablet ekstrak Bunga Rosella (Hibiscuss sabdariffa L.) menghasilkan formula optimal dengam metode Simplex Lattice Design dengan perbandingan Avicel PH 101 97,82\% : Laktosa 2,17\%. Avicel PH 101 dan Laktosa sebagai bahan pengisi memiliki pengaruh yang baik dalam menghasilkan sifat fisik tablet, meliputi uji keragaman bobot, uji kekerasan, serta uji kerapuhan.

\section{DAFTAR PUSTAKA}

Adetutu, A., Owoade, A.O. 2013. Hepatoprotective And Antioxidant Effect Of Hibiscus Polyphenol Rich Extract (Hpe) Against Carbon Tetrachloride (Cc14 ) -Induced Damage In Rats. Br. J. Med. Med. Res. 3(4), 15741586.

Asiani, W.T. 2012. Formulasi Tablet Efervesen dari Ekstrak Etanol Kelopak Bunga Rosella (Hibiscus sabdariffa L.). Yogyakarta : Universitas Gadjah Mada.

Depkes RI, 2014, Farmakope Indonesia, Edisi V, Departemen Kesehatan Republik Indonesia, Jakarta.

Elisabeth, V. 2018. Formulasi Sediaan Granul Dengan Bahan Pengikat Pati Kulit Pisang Goroho (Musa acuminafe L.) Dan Pengaruhnya Pada Sifat Fisik Granul. Pharmacon. Volume 7, No 4.

Hayatus Sa'adah dan Fudholi. 2011. Optimasi Formula Tablet Teoffilin Menggunakan Co-Prossed Exipients Campuran Laktosa dan Avicel PH 101. Universitas Gadjah Mada

Husni, E., Suharti, N., Atma, A.P.T. 2018. Karakterikstik Simplisia 
dan Ekstrak Daun Pacar Kuku (Lawsonia inermis Linn) serta Penentuan Kadar Fenolat dan Uji Aktivitas Antioksidan. Jurnal Sains Farmasi dan Klinis, Volume 5, No 1.

Mahadevan, N., Shivali and Kamboj, P. 2009. Hibiscus sabdariffa Linn.An Overview. Natural Product Radiance. Vol 8 (1) p : 77-83

Nova, L. 2013. Pengaruh Kondisi Penyimpanan Obat Terhadap Kualitas Tablet Vitamin C Di Puskesmas Kecamatan Pontianak Kota. Jurnal Mahasiswa Farmasi Fakultas Kedokteran UNTAN, Volume 3, No 1.

Parrot, E.L. 1971. Effect of Dissolution Media on Disintegran and Disolution of Hydroclortiazid Tablets. J. Pharm.Sci.

Rahman, L., Warnida, H., Djide, N. 2012. Pengaruh Fermentasi Sari Kedelai dengan Lactobacillus sp. terhadap Kadar dan Profil Kromatografi Lapis Tipis Genistein serta Formulasinya dalam Granul Effervescent. Jurnal Ilmu Kefarmasian Indonesia. Volume 10, No 2.

Raissi, S., R.E. Farzani. 2009. Statistical Process Optimation Through Multi-Response Surface Methodologhy, World Academy of Science, Enginerring and Technology,

Hayati, R. 2011. Pengaruh Suhu Pengeringan Terhadap Mutu Rosella Kering. Jurnal Floratek. Volume 6. No 1.
Siregar, CJP. dan Wikarsa, S. 2010. Teknologi Farmasi Sediaan Tablet. EGC : Jakarta

Sulaiman, T.N.S. 2007. Teknologi Dan Formulasi Sediaan Tablet. Yogyakarta: Fakultas Farmasi Universitas Gadjah Mada

Sylfania, F. 2013. Optimasi Formula Tablet Hisap Ekstrak Buah Mahkota Dewa (Phaleria macrocarpa [Scheff.] Boerl.) Menggunakan Campuran Pengisi Laktosa-Sorbitol Dengan Metode Simplex Lattice Design, Skripsi, Fakultas Farmasi, Universitas Muhammadiyah, Surakarta.

Voigt, R. 1995. Buku Pelajaran Teknologi Farmasi, diterjemahkan oleh Soendari Noerono, Gajah Mada University Press, Yogyakarta

Wacana, A.O. 2016. Optimasi Formula Sediaan Tablet Getah Kuning Tanaman Ashitaba (Angelica keiskei) Dengan Kombinasi Starlac® Dan Kalsium Fosfat Dibasik Menggunakan Metode Desain Faktorial, Fakultas Farmasi. Skripsi. Universitas Muhammadiyah Surakarta. 